\title{
Effects of the Variants of Activin Receptor-like Kinase- 1 and 2 on the Lipid Profile of Patients with Coronary Heart Disease
}

\section{Aktivin-benzeri Kinaz Reseptörleri-1 ve 2 Varyantlarının Koroner Arter Hastalarında Lipid Profiline olan Etkilerinin Araştırılması}

\author{
(D) Ayşegül Başak Akadam Teker¹, (D) Erhan Teker2, (D) Hülya Yılmaz Aydoğan³ \\ ${ }^{1}$ Giresun University Faculty of Medicine, Department of Medical Genetics, Giresun, Turkey \\ ${ }^{2}$ Giresun University Prof. Dr. A. İlhan Özdemir Training and Research Hospital, Clinic of Cardiology, Giresun, Turkey \\ 3 İstanbul University Aziz Sancar Institute of Experimental Medicine, Department of Molecular Medicine, İstanbul, Turkey
}

\begin{abstract}
Introduction: Coronary heart disease (CHD) due to atherosclerosis is a multifactorial disease with high morbidity caused by interaction of various genetic and environmental factors. Hyperlipidemia which is accepted as the most important risk factor for atherosclerosis; characterized by high concentration of low density lipoprotein (LDL) -cholesterol (LDL-C) and low concentration of high density lipoprotein (HDL)cholesterol (HDL-C). Epidemiological studies prove the inverse relationship between HDL-C levels and CHD. Apolipoprotein $\mathrm{A} 1$, the major protein of $\mathrm{HDL}$, is secreted as proprotein and then cleaved by C-terminal procollagen endoproteinase/bone morphogenetic protein-1 (BMP-1). Reporting of the role of BMP receptors in lipoprotein metabolism indicates that variations in these genes may be important. However, there are no studies in the literature about the variations in type I receptors for activin receptor-like kinase (ALK) 1 and ALK2 and its effects on lipid profile. In this study, it was aimed to determine the role of the gene variants of ALK1 (Q292P ve S333G) and ALK2 (R206H) receptors in the development of CHD and their effects on serum lipoprotein levels.
\end{abstract}

Methods: This study was carried out using a sample of 131 patients with CHD and 51 controls. ALK1 and ALK2 genotypes were determined by real-time polymerase chain reaction and technique.

Results: Genotype distributions of ALK1 and ALK2 were the same between the study groups $(p>0.05)$. Mutations in ALK1 and ALK2 were observed only in the patient group. ALK1 Q292P mutation and ALK2 R206H mutation exerted positive effects on the serum lipid profile.

Conclusion: The findings of our study suggested that mutations of $A L K 1$ and $A L K 2$ genes may contribute to antiatherogenic lipid profile and may protect against the development of CHD.

Keywords: Mutation, coronary hearth disease, ALK1, ALK2

\section{öZ}

Amaç: Aterosklerozdan kaynaklanan koroner kalp hastalığı (KKH) çeşitli genetik ve çevresel etmenlerin etkileşimden kaynaklanan morbimortalitesi yüksek multifaktöriyel bir hastalıktır. Ateroskleroz için en önemli risk faktörü kabul edilen hiperlipidemi; düşük yoğunluklu lipoprotein (LDL)-kolesterolün (LDL-K) yüksek konsantrasyonu ve yüksek yoğunluklu lipoprotein (HDL)-kolesterolün (HDL-K) düşük konsantrasyonu ile karakterizedir. Epidemiyolojik çalışmalar HDL-K seviyeleri ve KKH arasındaki ters ilişkiyi kanıtlamaktadır. HDL'nin bașısca proteini olan Apolipoprotein A1, proprotein olarak sekrete edilir ve sonra C-terminal prokollajen endoproteinaz/kemik morfogenezi ile ilişkili protein-1 (BMP-1) tarafından kesilir. BMP reseptörlerinin lipoprotein metabolizmasındaki görevlerinin bildirilmesi bu genlerdeki varyasyonların önemli olabileceğine işaret etmektedir. Ancak tipl reseptör aktivin reseptörü benzeri kinaz (ALK) 1 ve ALK2'ye ait varyasyonlar ve lipid profil'ine olan etkileri ile ilgili literatürde çalışma bulunmamaktadır. Biz çalışmamızda ALK2'ye ait R206H, ALK1 Q292P ve S333G gen varyantlarının KKH ile ilișkini ve lipoprotein metabolizması üzerine olan etkilerinin incelenmesini amaçladık.

Yöntemler: Çalıșma gruplarımız 131 KKH ve 51 erkek kontrolden oluşmuştur. ALK1 ve ALK2 genotipleri gerçek zamanlı polimeraz zincir reaksiyonu ile belirlenmiștir.

Bulgular: ALK1 ve ALK2 genotip dağılımları çalıșma gruplarında benzer gözlenmiştir. Ancak ALK1 ve ALK2 mutasyonları sadece hasta grubunda bulunmuștur. ALK1 Q292P mutasyonu ile ALK2 R206H mutasyonunun serum lipid profiline olumlu katkısını gözlemledik.

Sonuç: Çalışmamızın bulguları ALK1 ve ALK2 genlerine ait mutasyonların antiaterojenik lipid profiline katkı sağlayabileceği ve bu şekilde KKH gelişiminde koruyucu olabilecekleri izlenimini vermiștir.

Anahtar Kelimeler: Mutasyon, koroner kalp hastalığı, ALK1, ALK2 


\section{Introduction}

Atherosclerosis is a progressive and degenerative disease, usually beginning in childhood, showing clinical symptoms in middle age, caused by genetic and environmental factors, normal and modified lipoproteins, monocytes, macrophage foam cells, T lymphocytes, endothelial cells (ECS), smooth muscle cells and fibroblasts complex interactions (1). Coronary heart disease (CHD), which develops as a result of atherosclerosis, still remains a serious cause of death in the world, is responsible for about $50 \%$ of deaths in the United States and Europe and $34 \%$ in Turkey.

Bone morphogenetic protein (BMP) is a metalloproteinase belonging to the growth factor transducer beta (TGF- $\beta$ ) superfamily. They were first identified as factors that caused the formation of bone and cartilage. However, it was later determined that they also showed broad spectrum biological activities in different tissues including blood vessels, heart, kidney, neurons, liver and lung. Studies have shown that BMPs can also form osteal tissue in "extraosteal" organs, making this protein a candidate for atherosclerosis. Indeed, recent research has shown that BMP ligands increase in vascular calcific lesions associated with atherosclerosis, diabetes and chronic renal failure (2-9). BMPs transmit their signals through two types of receptors, type I and type II. Type I receptors are essential for signaling. Type II receptors are responsible for binding to ligands and expression of type I receptors. Type II receptors phosphorylate type I receptors in the stable complex formed by type I and type II receptors following ligand binding.

The type I receptor "activin receptor-like kinase (ALK1)" plays an active role in EC biology. ALK1 has often been studied in relation to angiogenesis. However, the demonstration that ALK1 is expressed in atherosclerotic lesions suggests that it also plays a role in atherogenesis (10). In addition, Kraehling and colleagues reported in their study that ALK1 is a new low-affinity, high-capacity receptor for low density lipoprotein (LDL) in ECS that functions during hypercholesterolemia and supports LDL transcytosis. The determination of direct binding of ALK1 to LDL, unlike lipoprotein receptor (LDLR), and the lack of down-regulation of this binding by sterols and Proprotein convertase subtilisin/kexin type 9 have made ALK1 a new beacon of hope for the treatment of atherosclerosis (11).

The type I activin A receptor, also known as ALK2, is a transmembrane serine/threonine kinase receptor and following BMP binding activates intracellular signaling pathways via Smad1/5, Erk1/2 and p38. The ALK2 receptor, showing more limited signal specificity, is sensitive to BMP-56-7 signals. ALK2 gene mutations cause the activation of BMP-specific intracellular signals without ligand binding to the receptor. In addition, the reporting that ALK1 expression is dependent on high density lipoprotein (HDL) induction to ALK2 indicates that variations in this gene may be important (12). Recent studies have shown evidence of the role of BMPs and their receptors in atherosclerosis $(8,10,12,13)$.

Considering this information, it is worth studying the variations of BMP receptors as new biological markers that may cause individual differences in the treatment of atherosclerosis, which is a very serious health problem.
In our study, we aimed to investigate the effects of R206h, ALK-1 Q292P and s333g missense mutations of ALK2 induced by HDL with antiatherogenic properties due to its role in reverse cholesterol transport on CHD development and lipoprotein metabolism.

\section{Methods}

For the analysis of the mutations identified in our study, the cases were included in the study based on the clinical criteria determined below, DNA belonging to these samples was prepared and purity determination was made and DNA levels were calculated and stored at $+4^{\circ} \mathrm{C}$ until the time of the study. In addition, after all individuals in the study groups were informed, informed consent form was obtained and they were included in the study. Our study was carried out by the ethics committee decision numbered 2010/702-194 taken from İstanbul University Faculty of Medicine Clinical Research Ethics Committee and was supported by İstanbul University Scientific Research Projects Unit (no: 11304).

R206H (rs number: 121912678) ALK-1 q292p and s333g of ALK2 were studied using real - time polymerase chain reaction method and enzyme-linked immunosorbent assay technique to determine serum apoprotein A1 level in the obtained DNA samples. The distribution of genotypes and alleles in patient and control groups was analyzed by statistical analysis and it was attempted to determine whether they posed a risk in disease development. In addition, as related to CHD risk factors, body mass index $(\mathrm{BMI})\left(\mathrm{kg} / \mathrm{m}^{2}\right)$, arterial hypertension $(\geq 140$ $\mathrm{mmHg}$ systolic blood pressure of $\geq 90 \mathrm{mmHg}$ diastolic blood pressure), hyperlipidemia (total cholesterol $>240 \mathrm{mg} / \mathrm{dL}$ and cholesterol $>250 \mathrm{mg} /$ $\mathrm{dL}$ ) were evaluated.

Two sample groups were used in this study.

In the first group, 138 angiography (-) male individuals were enrolled in the control group. Participants in the control group were not taking drugs with known effects on serum lipid levels during sample extraction (lipid-lowering drugs such as statins or fibrates, beta-blockers, diuretics or hormones).

The second group was made up of 131 male patients with angiography (+) diagnosed with CHD by coronary angiography method followed by the İstanbul University Department of Cardiology of the Faculty of Medicine. Six of the patients were on no medication, 1 was using phenofibrate and 124 were receiving statin treatment. And all but one of them were receiving antihypertensive treatment.

\section{Statistical Analysis}

Statistical analysis of this study was conducted using SPSS 20 package program. The statistical significance limit was taken as $p<0.05$.

Whether the data belonging to the patient and control groups comply with the normal distribution was analyzed with the KolmogorovSmirnov test. Student's t-test was used to determine body mass indexes, and chi-square $\left(\chi^{2}\right)$ and Fisher's exact tests were used to evaluate the differences between groups in the frequency of genotype and alleles. The Kruskal-Wallis method was used for comparing clinical and nonclinical parameters with alleles between the patient and control groups, 
and ANOVA and Student's t-test was used to examine the genotype. Gene counting method was used in calculations of allele frequency.

\section{Results}

Our study consisted of 131 CHD and 138 volunteer healthy controls followed at the İstanbul University Faculty of Medicine Department of Cardiology. The properties for the groups are given in Table 1. Accordingly, there were no statistically significant differences between the patient and the control group in terms of age, serum apoprotein A1, triglycerides, very-low-density lipoprotein (VLDL)-C, HDL-C and BMI values and alcohol consumption ( $p>0.05$ ). Cigarette consumption was high in the patient group compared to the control group (63.8\% in the patient group; $47 \%$ in the control group; $p=0.006$ ). Also in the patient group, systolic blood pressure $(p \leq 0.001)$, diastolic blood pressure $(p=0.008)$, total cholesterol $(p \leq 0.001)$, LDL-C $(p \leq 0.001)$ of total cholesterol/HDL-C ( $p \leq 0.001), \mathrm{HDL}-\mathrm{Cl} / \mathrm{LDL}-\mathrm{C}(\mathrm{p}=0.008)$ compared to the control group values were found to be low and statistically significant.

$94.6 \%$ of the individuals in our patient group use statins, $0.76 \%$ use fenofibrate type drugs, and $4.5 \%$ do not receive antihyperlipidemic treatment. In addition, all but one of our patients have hypertension and use antihypertensive drugs. We attribute the lower serum lipid/ lipoprotein and blood pressure values observed in the patient group compared to our control group to the use of medication.
The genotype and allele distributions of $A L K 1$ and $A L K 2$ gene mutations studied in patient and control groups are shown in Table 2 . When ALK1 Q292P and S333G and ALK2 r206h genotype distributions were examined in study groups, no statistically significant differences were observed. However, mutant genotypes of ALK1 and ALK2 genes were observed only in the patient group and no mutations were found in the control group (Table 2).

When the effect of ALK1 Q292P mutations on serum Apoprotein A1, lipoprotein levels, BMI and blood pressures were examined, serum triglycerides $(p=0.020)$, LDL-C $(p=0.045)$ and VLDL-C $(p=0.022)$ levels were significantly lower in the patients with mutant genotypes compared to those with no mutations. The effect of ALK1 S333g mutation on serum lipids, blood pressures and body mass index values was not observed $(p>0.05)$ (Table 3).

When the effect of ALK2 r206h mutation on serum Apoprotein A1, lipoprotein levels, BMI and blood pressures were examined in the patient group, serum LDL-K ( $p=0.017)$ levels were significantly lower in individuals with mutant genotypes compared to non-mutant individuals (Table 4).

Since ALK1 and ALK2 variants were not found in the control group, we were unable to evaluate their effect on lipid profile, BMI and blood pressures.

Table 1. Characteristics of the groups

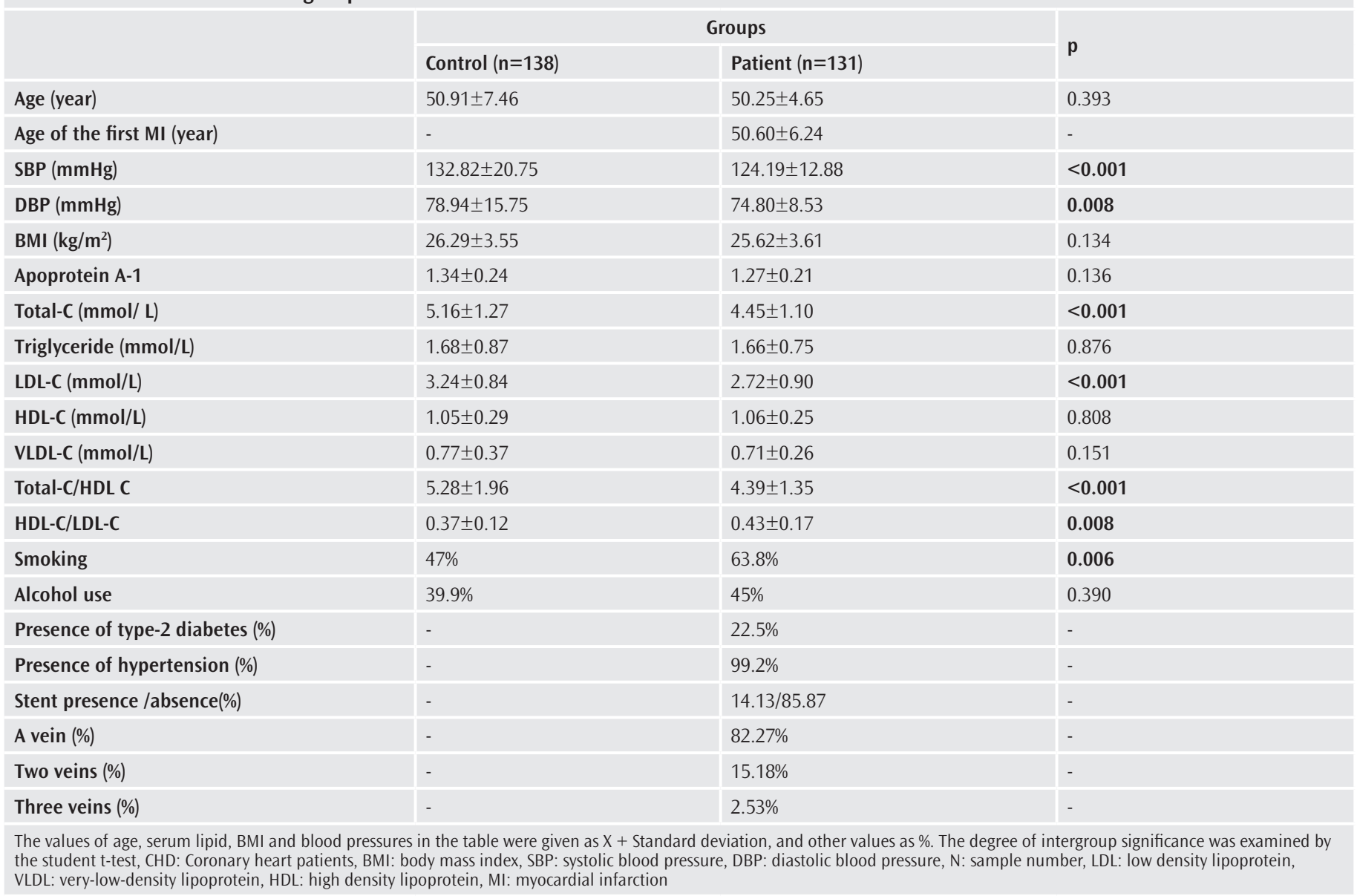


Table 2. Distribution of ALK1 and ALK2 genotypes in the groups

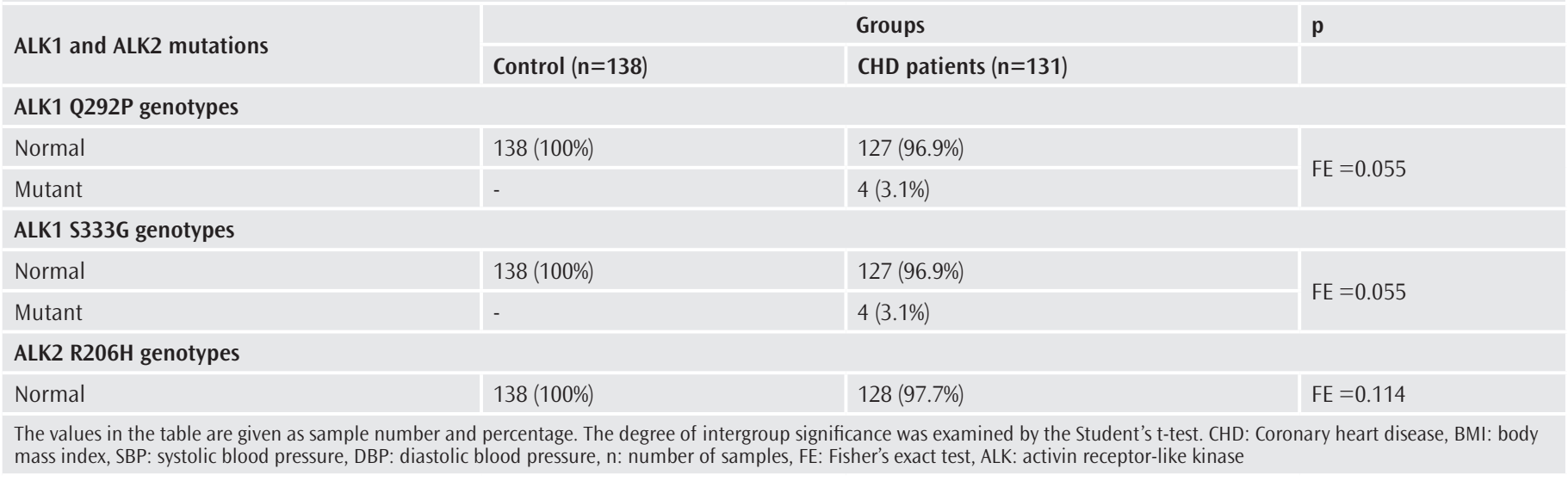

Table 3. Effect of ALK1 Q292P and S333S mutations on serum lipid profile, blood pressures and body mass index in patient group

\begin{tabular}{|c|c|c|c|}
\hline & & ALK1 Q29 & \\
\hline & Normal & Mutant & $\mathrm{p}$ \\
\hline Apoprotein-A1 & $1.28 \pm 0.21$ & $1.10 \pm 1.17$ & 0.165 \\
\hline Triglyceride $(\mathrm{mmol} / \mathrm{L})$ & $1.68 \pm 0.76$ & $1.15 \pm 0.27$ & 0.020 \\
\hline HDL-C (mmol/L) & $1.06 \pm 0.25$ & $1.17 \pm 0.40$ & 0.622 \\
\hline BMI $\left(\mathrm{kg} / \mathrm{m}^{2}\right)$ & $25.60 \pm 3.65$ & $26.24 \pm 1.99$ & 0.581 \\
\hline SBP $(\mathrm{mmHg})$ & $124.25 \pm 12.94$ & $122.50 \pm 12.58$ & 0.790 \\
\hline $\mathrm{DBP}(\mathrm{mmHg})$ & $74.88 \pm 8.62$ & $72.50 \pm 5.00$ & 0.419 \\
\hline & ALK1 S333G m & & \\
\hline Triglyceride (mmol/L) & $1.66 \pm 0.75$ & $1.66 \pm 0.75$ & 0.999 \\
\hline HDL-C(mmol/L) & $1.06 \pm 0.25$ & $1.06 \pm 0.23$ & 0.983 \\
\hline LDL-C (mmol/L) & $2.70 \pm 0.89$ & $3.20 \pm 1.08$ & 0.281 \\
\hline VLDL-C (mmol/L) & $0.71 \pm 0.26$ & $0.68 \pm 0.14$ & 0.790 \\
\hline BMI $\left(\mathrm{kg} / \mathrm{m}^{2}\right)$ & $25.56 \pm 3.56$ & $28.13 \pm 5.39$ & 0.225 \\
\hline SBP (mmHg) & $124.25 \pm 12.88$ & $122.50 \pm 15.00$ & 0.790 \\
\hline $\mathrm{DBP}(\mathrm{mmHg})$ & $74.80 \pm 8.53$ & $75.00 \pm 10.0$ & 0.964 \\
\hline
\end{tabular}

The values in the table are given as X + standard deviation. The degree of intergroup significance was examined by the student t-test. BMI: Body mass index, SBP: systolic blood pressure, DBP: diastolic blood pressure, LDL: low density lipoprotein, VLDL: very-low-density lipoprotein, HDL: high density lipoprotein, ALK: activin receptor-like kinase

\section{Discussion}

Atherosclerotic CHD is one of the greatest threats to Global Health (14). Atherosclerosis is a complex disease influenced by various environmental factors and accompanied by many genetic variations with low penetration (15). For CHD with high morbimortality (16) endothelial dysfunction, inflammation, abnormal lipoprotein and homocysteine metabolism are very important risk factors (17).

In recent studies, the presentation of evidence that BMPs and their receptors play a role in atherosclerosis has caused researchers to turn to these proteins. The results of our study published in 2018 show that the BMP1 5'UTR + $104(\mathrm{~T} / \mathrm{C})$ variation may affect serum Apo A1 and lipoprotein levels due to statin therapy and thus contribute to the development of CHD (13). Studies of BMPs remain current and are continuing rapidly, but studies of BMP receptors that enable BMP signaling and their effects on atherosclerosis are limited. The variations in these proteins appear to be a very current and important issue, as they can affect the progressive aspect of atherosclerosis.

In our study, we studied the frequency of ALK1 type I receptors Q292p and S333G and ALK2 R206h mutations in CHD and their effects on lipoproteins. The relationship between ALK1 and ALK2 and CHD and the effect of these variants on lipoproteins has not been found in 
Table 4. Effect of ALK2 R206H mutation on serum lipid profile, blood pressures and body mass index in CHD patient group

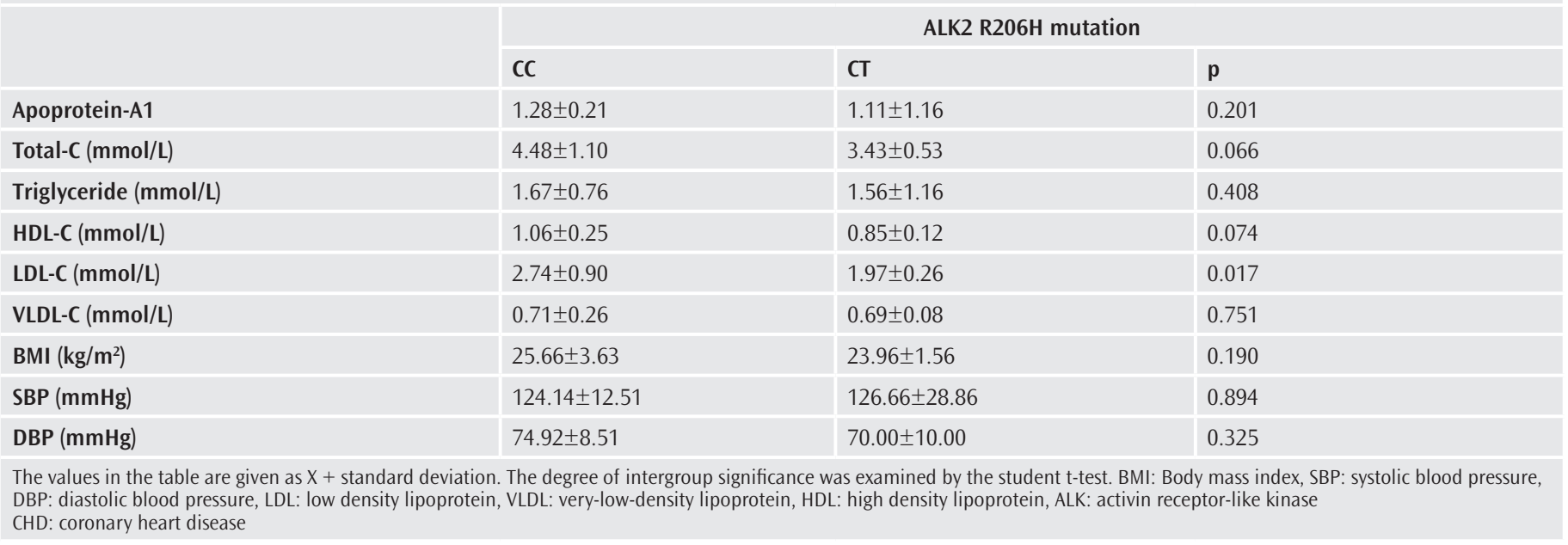

the literature. For this reason, we could not find the opportunity to compare our results. In general, mutations on ALK1 have been associated with the development of direct connections between arteries and vessels, or with hereditary hemorrhagic telangiectasia (HHT 2), which is autosomal dominant inheritance and systemic fibrovascular dysplasia, characterized by arteriovenous malformations (18-21). There are publications reporting that ALK-1 mutations are associated with pulmonary hypertension in HHT patients $(22,23)$.

Studies pointing out the role of ALK1 in atherosclerosis have mainly drawn attention to TGF-family signaling, and according to independent study data, inhibition of BMP signal reduces the formation of atherosclerotic plaques $(24,25)$. Although until recently there was little evidence of a link between ALK1 and atherosclerosis, an increase in ALK1 expression was also observed in atherosclerotic lesions, based on data from two studies in mice (26) and humans (10).

ALK1 has two independent roles in atherosclerosis through direct binding of LDL to extracellular domein to mediate LDL uptake and provide BMP signaling. In addition, Kraehling and colleagues (11) reported that ALK1 facilitates LDL uptake but does not target LDL for impairment, while LDLR and ALK1 overexpression increase fluorescence labeled LDL [dioctadecylindocarbocyanine (Dil)-LDL] uptake, they did not observe the effect of ALK2 overexpression on Dil-LDL uptake.

According to the results of our study, serum triglycerides, LDL-C and VLDL-C levels were statistically significantly lower in individuals with ALK1 Q292P mutant genotype than in non-mutant individuals. According to this data, it may be possible to say that ALK1 Q292P mutation shows antiatherogenic properties when its positive effect on lipid profile is evaluated.

ALK2 enables the rearrangement of ALK1. However, gene deletion experiments produce different phenotypes, indicating that the respective target genes of ALK1 and ALK2 are different. ALK1 deficiency is associated with HHT and the formation of arteriovenous malformations, while ALK2 affects the development of cardiac output pathway and aortic derivatives. A high level of ALK2 relative to ALK3 and ALK6 may alter the inflammatory effects of BMP-2/4 in the endothelium (12).
Yao et al. (24) showed that HDL promotes ALK2 expression in ECs, which allows induction of ALK-1, vascular endothelial growth factor (VEGF) and matrix Gla protein (MGP). These investigators showed that the HDL induction of ALK2 is dependent on the BMP signal and also affects the correlation of a repressive homeodomain protein (Msh homeobox2) MSX2 and the activating homeodomain proteins DLX3 and DLX5 (homeobox protein) with the ALK2 gene. The significance of these findings is confirmed in apoA1 transgenic mice with high HDL levels and resistant to atherogenesis. Mice mentioned show similar changes in aortic gene expression as seen in in vitro ECs. In this way, HDL protects the arterial wall by increasing the BMP response system, which allows the increase of VEGF, essential for endothelial survival, and the increase of MGP, which prevents excessive BMP activity and vascular calcification.

According to the results of our study, LDL-C levels were statistically significantly lower in individuals with ALK2 R206h mutant genotype than in non-mutant individuals. According to this data, it may be possible to say that ALK2 R206h mutation shows antiatherogenic properties when its positive effect on lipid profile is evaluated.

\section{Conclusion}

We observed ALK1 Q292P and S333G and ALK2 R206h mutations in our study, albeit with a low frequency, only in the patient group. We didn't find any mutations in the control group. Therefore, we were unable to assess the effect of these mutations on control group characteristics. However, we observed the positive contribution of the ALK1 Q292P mutation and the ALK2 R206H mutation to the serum lipid profile in the patient group. The findings of our study suggest that mutations in the $A L K 1$ and ALK2 genes, which are BMP receptors, may contribute to the antiatherogenic lipid profile and thus be protective in the development of CHD. We believe that the interaction of BMP protein and signaling pathway variants with serum lipids deserves a better understanding by continuing our study in the study group with a larger sample.

\section{Ethics}

Ethics Committee Approval: Our study was carried out by the ethics committee decision numbered 2010/702-194 taken from İstanbul University Faculty of Medicine Clinical Research Ethics Committee and 
was supported by İstanbul University Scientific Research Projects Unit (no: 11304).

Informed Consent: Informed consent was obtained from all patients.

Peer-review: Externally peer-reviewed.

Authorship Contributions: Design - A.B.A.T., H.Y.A.; Data Collection or Processing - A.B.A.T., E.T.; Analysis or Interpretation - A.B.A.T., H.Y.A.; Literature Search - A.B.A.T., H.Y.A.; Writing - A.B.A.T.

Conflict of Interest: No conflict of interest was declared by the authors.

Financial Disclosure: Supported by İstanbul University Scientific Research Projects Unit (no: 11304).

\section{References}

1. Page IH. Atherosclerosis; an introduction. Circulation 1954; 10: 1-27.

2. Zhang M, Sara JD, Wang FL, Liu LP, Su LX, Zhe J, et al. Increased plasma bmp-2 levels are associated with atherosclerosis burden and coronary calcification in type 2 diabetic patients. Cardiovasc Diabetol 2015; 14: 64.

3. Chang K, Weiss D, Suo J, Vega JD, Giddens D, Taylor WR et al. Bone morphogenic protein antagonists are coexpressed with bone morphogenic protein 4 in endothelial cells exposed to unstable flow in vitro in mouse aortas and in human coronary arteries: role of bone morphogenic protein antagonists in inflammation and atherosclerosis. Circulation 2007; 116: 1258-66.

4. Yung LM, Sánchez-Duffhues G, Ten Dijke P, Yu PB. Bone morphogenetic protein 6 and oxidized low-density lipoprotein synergistically recruit osteogenic differentiation in endothelial cells. Cardiovasc Res 2015; 108: 278-87.

5. Csiszar A, Ahmad M, Smith KE, Labinskyy N, Gao Q, Kaley G, et al. Bone morphogenetic protein-2 induces proinflammatory endothelial phenotype. Am J Pathol 2006; 168: 629-38.

6. Csiszar A, Labinskyy N, Jo H, Ballabh P, Ungvari Z. Differential proinflammatory and prooxidant effects of bone morphogenetic protein-4 in coronary and pulmonary arterial endothelial cells. Am J Physiol Heart Circ Physiol 2008; 295: H569-77.

7. Li X, Yang HY, Giachelli CM. BMP-2 promotes phosphate uptake, phenotypic modulation, and calcification of human vascular smooth muscle cells. Atherosclerosis 2008; 199: 271-7.

8. Nakagawa Y, Ikeda K, Akakabe Y, Koide M, Uraoka M, Yutaka KT, et al. Paracrine osteogenic signals via bone morphogenetic protein-2 accelerate the atherosclerotic intimal calcification in vivo. Arterioscler Thromb Vasc Biol 2010; 30: 1908-15.

9. Buendía P, de Oca AM, Madueño JA, Merino A, Martín-Malo A, Aljama P, et al. Endothelial microparticles mediate inflammation-induced vascular calcification. FASEB J 2015; 29: 173-181.

10. Yao Y, Zebboudj AF, Torres A, Shao E, Bostrom K. Activin-like kinase receptor 1 (ALK1) in atherosclerotic lesions and vascular mesenchymal cells. Cardiovasc Res 2007; $74: 279-89$.

11. Kraehling JR, Chidlow JH, Rajagopal C, Sugiyama MG, Fowler JW, Lee MY, et al. Genome-wide rnai screen reveals alk1 mediates Idl uptake and transcytosis in endothelial cells Nat Commun 2016; 7: 13516.
12. Yao Y, Shao ES, Jumabay M, Shahbazian A, Ji S, Kristina I. Boström. High density lipoproteins affect endothelial bmp-signaling by modulating expression of the activin-like kinase receptor 1 and 2. Arterioscler Thromb Vasc Biol 2008; 28: 2266-74.

13. Akadam Teker B, Ozkara G, Kurnaz Gomleksiz O, Bugra Z, Teker E, Ozturk O, et al. BMP1 5'UTR+104 T/C gene variation: can be a predictive marker for serum $\mathrm{HDL}$ and apoprotein $\mathrm{A} 1$ levels in male patients with coronary heart disease. Mol Biol Rep 2018; 45: 1269-76.

14. Benjamin EJ, Blaha MJ, Chiuve SE, Cushman M, Das SR, Deo R, et al. Heart disease and stroke statistics-2017 update: a report from the American heart association. Circulation 2017; 135: e146-e603.

15. Liu L, Li Y, Tollefsbol TO. gene-environment interactions and epigenetic basis of human diseases. Curr Issues mol biol 2008; 10: 25-36.

16. Raposo M, Sousa P, Nemeth S, Couto A, Santos M, Pinheiro J, et al. Polymorphism in cardiovascular diseases (cvd) susceptibility loci in the azores islands (portugal) Open j genet 2011; 1: 48-53.

17. Roy H, Bhardwaj S, Yla-Herttuala S. Molecular Genetics of atherosclerosis Hum Genet 2009: 467-91.

18. Guttmacher AE, Marchuk DA, White RI Jr. Hereditary haemorrhagic telangiectasia. N Engl J Med 1995; 333: 918-24.

19. Johnson DW, Berg JN, Baldwin MA, Gallione CJ, Marondel I, Yoon SJ, et al. Mutations in the activin receptor-like kinase 1 gene in hereditary haemorrhagic telangiectasia type 2. Nat Genet 1996; 13: 189-95.

20. Plauchu H, de Chadarevian JP, Bideau A, Robert JM. Age-related clinical profile of hereditary haemorrhagic telangiectasia in an epidemiologically recruited population. Am J Med Genet 1989; 32: 291-7.

21. Vincent P, Plauchu H, Hazan J, Faure S, Weissenbach J, Godet J. A third locus for hereditary haemorrhagic telangiectasia maps to chromosome 12q. Hum Mol Genet 1995; 4: 945-9.

22. Trembath RC, Thomson JR, Machado RD, Morgan NV, Atkinson C, Winship I, et al. Clinical and molecular genetic features of pulmonary hypertension in patients with hereditary hemorrhagic telangiectasia. N Engl J Med 2001; 345: 325-34.

23. Selva-O'Callaghan A, Balada E, Serrano-Acedo S, Aznar CPS, Ordi-Ros J. Mutations of activin-receptor-like kinase 1 (ALK-1) are not found in patients with pulmonary hypertension and underlying connective tissue disease. Clin Rheumatol 2007; 26: 947-9.

24. Yao Y, Bennett B, Wang X, Rosenfeld ME, Giachelli C, Luis AJ, et al. Inhibition of bone morphogenetic proteins protects against atherosclerosis and vascular calcification. Circ Res 2010; 107: 485-94.

25. Derwall M, Malhotra R, Lai CS, Beppu Y, Aikawa E, Seehra JS, et al. Inhibition of bone morphogenetic protein signaling reduces vascular calcification and atherosclerosis. Arterioscler Thromb Vasc Biol 2012; 32: 613-22.

26. Korff T, Aufgebauer K, Hecker M. Cyclic stretch controls the expression of CD40 in endothelial cells by changing their transforming growth factor-beta1 response. Circulation 2007; 116: 2288-97. 